\title{
The Minimum Inhibition and Growth Concentrations for Controlling Fungal Infections as well as Ghost Cells Preparation: Aspergillus flavus as a Model
}

\author{
Nawal Abd El-Baky ${ }^{\S 1}$, Mona M Sharaf ${ }^{1}$, Eman Amer ${ }^{1}$, Hoda Reda Kholef ${ }^{1}$, Mohamed Zakaria Hussain ${ }^{2}$, Raoufa Ahmed \\ Abdel Rahman ${ }^{3}$ and Amro A Amara*\$1
}

${ }^{1}$ Protein Research Department,Genetic Engineering and Biotechnology Research Institute, City for Scientific Research and Technological Applications, Alexandria, Egypt

${ }^{2}$ Department of Microbiology and Immunology, Faculty of Medicine, Tanta University, Tanta

${ }^{3}$ Pharmaceutical Bio-Products Research Department, Genetic Engineering and Biotechnology Research Institute, City for Scientific Research and Technological Applications, Alexandria, Egypt

$\S$ Both authors contributed equally to this study

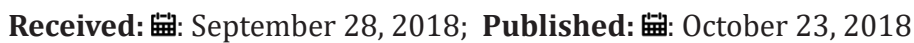

*Corresponding author: Amro Abd Al Fattah Amara, The head of the Protein Research Department, City for Scientific Research and Technological Applications Universities and Research Centre District, New Borg El-Arab, Egypt

\begin{abstract}
There is an increasing interest toward the understanding of the important fungus, Aspergillus flavus, which has a high impact on our health and economy. Controlling such microbe could be achieved by evacuating its cells using simple tool. Recently, the Sponge-Like protocol for bacterial ghosts' preparation was introduced. Then, this protocol concept was extended to include not only bacterial cells but also yeast cells as well as viruses. In this study, for the first time we applied this protocol to pathogenic fungi as Aspergillus flavus turning it to unviable, dead and evacuated ghost cells. We introduce the idea of using the minimum growth concentration (MGC) and the minimum inhibition concentration (MIC) for controlling Aspergillus flavus and other type of fungi either in our food or those infecting us. Using mixture of compounds proves to have effect on certain microbes upon the use of their minimum effect, which could be a solution for treating many diseases without damaging the cells and tissues as well as our organs. A. flavus which is responsible for causing different superficial infections besides its ability to produce hazardous aflatoxins was used as a model in this study. The future will show an increasing interest in this protocol either for ghost cells preparation or controlling pathogens with minimum side effects of the used destabilizing and killing compounds or drugs. Any chemical compound that could achieve the same goal is invited. We strongly recommend and encourage conducting research in this field using the same or similar tactics and idea.
\end{abstract}

Abbreviations: Minimum Growth Concentration (MGC), Minimum Inhibition Concentration (MIC), Chronic Cavitary Pulmonary Aspergillosis (CCPA), Allergic Bronchopulmonary Aspergillosis (ABPA), Allergic Fungal Sinusitis (AFS), Phosphate Buffered Saline (PBS), Bovine Serum Albumin (BSA), Transmission Electron Microscope (TEM).

\section{Introduction}

Controlling different types of fungi can be achieved by many tactics. A major tactic is based only on using closed dry conditions that inhibit the growth of any microbe. Different studies focused on Aspergillus fumigatus. However, there is an increasing interest in studying A. flavus which is the second leading cause of invasive aspergillosis and it is the most common cause of superficial infections. A. flavus invasive infection in mice shows 100 -fold more virulence than $A$. fumigatus $[1,2]$. Link who was the first to describe A. flavus. A. flavus is second only to A. fumigatus as the cause of human invasive aspergillosis. Moreover, it is the main cause for infecting insects among Aspergillus species [3]. It causes diseases in economically important crops, such as maize and peanuts, and produces potent harmful mycotoxins.
A. flavus has a worldwide distribution because of its production of numerous airborne conidia, that can be easily dispersed by air and insects. A. flavus grows better with water activity of 0.86 0.96 [4]. The optimum temperature for A. flavus to grow is $37^{\circ} \mathrm{C}$, which contributes to its pathogenicity in humans. A. flavus can be found in soil, outdoor air, or air and water of houses and hospitals. Therefore, numerous epidemics of invasive aspergillosis have been associated with construction and/or renovation activities in and around hospitals [5], as these activities noticeably increase the number of spores in the air. In two studies from Iran, A. flavus was the most predominant Aspergillus species in the air of hospital wards and homes [1,6]. A. flavus is responsible for different kinds of infections such as cutaneous infection to wound, central 
nervous system, osteoarticular and urinary tract. It causes chronic cavitary pulmonary aspergillosis (CCPA), aspergilloma, allergic bronchopulmonary aspergillosis (ABPA), keratitis, endophthalmitis, endocarditis, pericarditis, and rhinosinusitis as well as allergic fungal sinusitis (AFS) and sinus aspergilloma. Evacuating microbes from their cytoplasmic content is a natural phenomenon [7-8] and others reported that pores could be introduced to the microbial cells because of different mechanisms [9-12]. Such as the evacuation of gram-negative bacteria by the bacteriophage infections [7].

The bacteriophage $E$ lysis gene is used for evacuating the cells and turning them to ghosts by controlling its expression using heat sensitive promoter [11-15]. Recently, the Sponge Like protocol was introduced [8]. Its main concept is using active chemical compounds that could introduce pores in the microbes and degrade the DNA at concentrations which did not change the surface antigens or the 3D structure. This enables evacuating gram-negative and grampositive bacteria, eukaryotes and viruses [16-19]. SDS was proved to have the ability to perturb and destabilize cell wall/plasma membrane of yeasts and fungi at very low concentration [20].

The main concept of Sponge Like protocol was established by using white egg lysozyme. The idea of using egg lysozyme establishes an emergence protocol for oral vaccination [7]. Other enzymes, chemicals, and proteins that affect the cell wall of microbes are invited. In this study, A. flavus as a model for pathogenic fungi was prepared as ghosts. We are introducing for the first time the concept of using the MIC and the MGC for controlling microbes aiming to reduce the effect on the treated uninfected tissues and organs.

\section{Materials and Methods}

\section{Fungal Strain}

A. flavus strain used in this study was kindly identified and obtained from Al-Azhar University Mycology Center (Cairo, Egypt).

\section{Cultivation Conditions}

The A. flavus strain was cultivated in one litre flask contains 500 $\mathrm{mL}$ Sabouraud's dextrose broth at $28^{\circ} \mathrm{C}$ for 7 days at $150 \mathrm{rpm}$.

\section{Determination of the MIC and MGC values for $\mathrm{NaOH}$, SDS, $\mathrm{NaHCO}_{3}$ and $\mathrm{H}_{2} \mathrm{O}_{2}$}

Standard broth microdilution susceptibility assay for determining the MIC values for each of $\mathrm{NaOH}, \mathrm{SDS}, \mathrm{NaHCO}_{3}$ and $\mathrm{H}_{2} \mathrm{O}_{2}$ was conducted. MIC value for each compound was calculated as well as the concentration which allows first fungal growth which is abbreviated as MGC (the concentration showing first growth after the MIC).

\section{Randomization Experiment}

Three experiments were conducted to map the best preparation conditions either during the cell's cultivation or during the ghost cells preparation. The different variables were four chemical compounds representing SDS, $\mathrm{H}_{2} \mathrm{O}_{2}, \mathrm{NaHCO}_{3}$, and $\mathrm{NaOH}$, and three physical parameters represented as cultivation temperature, shaking rate during treatment, and the cultivation time. The seven variables were randomized according to the design in Table 1. Each variable of the four used chemical compounds was represented at two levels (high and low), which are donated by +1 (MIC) and -1 (MGC) as in Table 1, except for $\mathrm{NaOH}$ that was used only at +1 level. The +1 in shaking conditions refers to shaking at $150 \mathrm{rpm}$ during the different treatments while -1 refers to static incubation during treatment, +1 in growth time represents cultivation for 10 days while -1 represents cultivation for 5 days, -1 in growth temperature refers to cultivation at $25^{\circ} \mathrm{C}$.

The biomass of the different cultivation conditions was collected and washed gently by $0.5 \%$ saline and recentrifuged at $6000 \mathrm{rpm}$ for $10 \mathrm{~min}$. The supernatant was then discarded. $5 \mathrm{X}$ stock for each of $\mathrm{NaOH}, \mathrm{SDS}, \mathrm{NaHCO}_{3}$ and $2 \mathrm{X}$ stock for $\mathrm{H}_{2} \mathrm{O}_{2}$ were prepared from both +1 (MIC) and -1 (MGC), which were determined as mentioned above. All the experiments were conducted in three steps. The first step contains $\mathrm{NaOH}, \mathrm{SDS}, \mathrm{NaHCO}_{3}$ where $1 \mathrm{ml}$ from each was added to $1 \mathrm{ml}$ water and finally $1 \mathrm{ml}$ of the fungal suspension $(0.5 \mathrm{gm}$ of the fungus mat $/ \mathrm{ml}$ ) was added to get a final concentration of each of $\mathrm{NaOH}, \mathrm{SDS}, \mathrm{NaHCO}_{3}$ equal to $1 \mathrm{X}$. The second step contains $\mathrm{H}_{2} \mathrm{O}_{2}$. The $\mathrm{H}_{2} \mathrm{O}_{2}$ was used as $2 \mathrm{X}$ and one $\mathrm{ml}$ of the fungal suspension was added to reach final concentration of $\mathrm{H}_{2} \mathrm{O}_{2}$ equal to $1 \mathrm{X}$. After each treatment step, the supernatant was collected by centrifuging the fungus at $6000 \mathrm{rpm}$. After that, the fungal pellet was washed using $1 \mathrm{X}$ phosphate buffered saline (PBS) (alternatively common saline solution can be used). In the third step, the cell pellets were washed using $60 \%$ Ethanol and left at room temperature. After each of the above washing steps and centrifugation the supernatant was preserved to determine the amount of the released protein and DNA.

\section{Determination of the DNA Concentration}

The concentration of DNA in the supernatant after each step for each randomization experiment was determined by measuring the absorbance at $260 \mathrm{~nm}$. Quartz cuvette was used. An extinction 260 $=1$ corresponds to $50 \mu \mathrm{g}$ dsDNA $\mathrm{mL}^{-1}[21]$.

\section{Determination of the Protein Concentration}

Concentration of released protein from each step in each randomization experiment (the different supernatants) was determined using the spectrophotometer at $280 \mathrm{~nm}$. Quartz cuvette was used. The protein concentration was derived from bovine serum albumin (BSA) standard curve [21].

\section{Determination of the Fungal Viability}

The various fungal ghost preparations were investigated for the possibility of the presence of any viable cells by subjecting them to growth on Sabouraud's dextrose agar plates at $28^{\circ} \mathrm{C}$ for 7 days.

\section{Transmission Electron Microscope for Examination of $A$.} Flavus Ghost Cells

Transmission electron microscope (JEOL TEM 100 CX) was used for the examination of $A$. flavus ghost cells. 


\section{Results and Discussion}

After introducing the Sponge-like protocol for bacterial ghost preparation, the protocol showed success with all treated microbes. The use of the Sponge-Like protocol expands its scope for preparing microbes for immunological applications to be used as a drug delivery system. Yeast, which is a big cell if compared with bacterial cells, was used as a gossypol acetic acid delivery system. The protocol itself was modified; some of its components were replaced such as $\mathrm{NaHCO}_{3}$ was used instead of $\mathrm{CaCO}_{3}$ in some preparations. $\mathrm{NaHCO}_{3}$ showed more activity with eukaryotic cells. Also, it was extended to involve enzymes activity. Lysozyme other than chemical compounds could be found everywhere; in egg white of the birds [22]. Lysozyme could lyse nearly all the bacterial cells and if used at the correct concentration it can turn the cells to ghost cells rather than degrading it.

In this study, a further application to the protocol was studied. One of the major problems in using drugs as antimicrobial or antitumor agents is their concentration and selectivity. Using high dosage could kill microbes and cancer cells but also could damage severely the normal cells, tissues and organs. Amara (2017) highlighted the possibility of using adequate concentration for minimizing the side effects of the used antimicrobial agents. Each microbe or cell should be studied as a case by case study [23]. As described earlier in the first protocol, the main feature that distinguishes this protocol from others was the determination of both MIC and MGC. After improving the Sponge-Like protocol and proving its efficacy, it becomes clear that different microbes have different responses to the used chemicals and thus they show different MIC and MGC values. One of the benefits of this protocol that it can be used for strain differentiation rather than ghost cells preparation. Additionally, enzymes and proteins are able to introduce pores in the microbes when used at their MIC and MGC values $[24,25]$. The white egg lysozyme was used to induce an emergence protocol for ghost cells preparation that could be used globally [24].

A.flavus was selected as a model pathogenic fungus to be controlled with this protocol. The MIC and MGC values of different used chemicals were determined [26]. $\mathrm{NaOH}, \mathrm{SDS}, \mathrm{H}_{2} \mathrm{O}_{2}$, and $\mathrm{NaHCO}_{3}$ showed MIC values of $0.01 \mathrm{~g} / \mathrm{ml}, 0.0001 \mathrm{~g} / \mathrm{ml}, 0.15 \mathrm{ml} /$ $\mathrm{ml}$, and $0.1 \mathrm{~g} / \mathrm{ml}$, respectively, while gave MGC values of $0.001 \mathrm{~g} /$ $\mathrm{ml}, 0.00001 \mathrm{~g} / \mathrm{ml}, 0.015 \mathrm{ml} / \mathrm{ml}$, and $0.01 \mathrm{~g} / \mathrm{ml}$, respectively. After determining MIC and MGC for such compounds against $A$. flavus, three randomization experiments were conducted. Results of these randomization experiments are summarized in Table 2 . The results in Table 2 show that experiment 2 gave the best result. In experiment 2 as in Table 1, each of $\mathrm{NaOH}, \mathrm{SDS}$ and $\mathrm{NaHCO}_{3}$ were used in their +1 value. The shaking rate during treatment, the cultivation time and the cultivation temperature were in their -1 value. In a previous study (data not shown), high shaking rate during treatment caused a sort of hyphal intertwining and shrinking which was avoided in this study [21]. Using SDS in its -1 value in experiment 1 might be responsible for the decrease in the cells quality if compared by experiment 2. Using SDS and $\mathrm{NaHCO}_{3}$ in their -1 value also lead to decrease in the cell's quality as in experiment 3.

Table 1: The randomization experiments for ghost cells preparation including 7 variables in +1 and -1 or only +1 or -1 .

\begin{tabular}{|c|c|c|c|c|c|c|c|}
\hline $\begin{array}{c}\text { Experiment } \\
\text { Number }\end{array}$ & $\mathbf{N a O H}$ & $\mathbf{S D S}$ & $\mathbf{N a H C O}_{3}$ & $\mathbf{H}_{2} \mathbf{O}_{2}$ & $\begin{array}{c}\text { Shaking Rate during } \\
\text { Treatment }\end{array}$ & Cultivation Time & $\begin{array}{c}\text { Cultivation } \\
\text { Temperature }\end{array}$ \\
\hline 1 & +1 & -1 & +1 & +1 & +1 & -1 & -1 \\
\hline 2 & +1 & +1 & +1 & -1 & -1 & -1 & -1 \\
\hline 3 & +1 & -1 & -1 & +1 & -1 & +1 & -1 \\
\hline
\end{tabular}

Table 2: The results of randomization experiments for ghost cells preparation.

\begin{tabular}{|c|c|c|c|c|c|c|c|}
\hline \multirow{2}{*}{$\begin{array}{l}\text { Experiment } \\
\text { Number }\end{array}$} & \multicolumn{2}{|c|}{$\mathrm{NaOH} / \mathrm{SDS} / \mathrm{NaHCO}_{3}$} & \multicolumn{2}{|c|}{$\mathbf{H}_{2} \mathbf{O}_{2}$} & \multicolumn{2}{|c|}{ Ethanol (60\%) } & \multirow{2}{*}{ Cell Quality \% } \\
\hline & DNA $(\mu \mathrm{g} / \mathrm{ml})$ & Protein $(\mathrm{mg} / \mathrm{ml})$ & DNA $(\mu \mathrm{g} / \mathrm{ml})$ & Protein $(\mathrm{mg} / \mathrm{ml})$ & DNA $(\mu \mathrm{g} / \mathrm{ml})$ & Protein $(\mathrm{mg} / \mathrm{ml})$ & \\
\hline 1 & 4.85 & 0.112 & 17.1 & 0.104 & 2.1 & 0.11 & $65 \%$ \\
\hline 2 & 34 & 0.764 & 0.4 & 0.009 & 2.25 & 0.038 & $78 \%$ \\
\hline 3 & 5.5 & 0.163 & 8.2 & 0.096 & 0.8 & 0.004 & $55 \%$ \\
\hline
\end{tabular}

In experiment 2 , the effect of $\mathrm{H}_{2} \mathrm{O}_{2}$ is not clear where only $0.4 \mu \mathrm{g} /$ ml DNA was released, which is less than experiments 1 and 3. This could be explained by the fact that most of DNA was lost at step 1. High DNA (cytoplasmic loss) was observed in experiment 2 at step 1 due to the use of +1 value with the three used chemical compounds [27]. In general, DNA/Protein release is highest in experiment 2. No growth was obtained on Sabouraud's dextrose agar plates after ghost cells cultivation from any of the three experiments which prove the loss of the cytoplasmic content during the process and the death of the fungus. However, the hyphae elongation was not definitely known to occur after which of the three steps of ghost cells preparation [28,29]. The images of the transmission electron microscope prove the graduated loss of the cytoplasmic content upon treatment (Figure 1). Small pores in fungal cell wall were observed. These small pores enable loss of the cytoplasmic content. However, big pores guarantee complete evacuation to the cytoplasmic content. Even after treatment, the cell wall still has its 3D structure $[7,30,31]$. This study succeeded to turn A. flavus to ghost cells. The different treatments show different results which prove the sensitivity of the process. The electron microscope results 
prove the evacuation of the cells from their cytoplasmic content. By determining the MIC and the MGC of each compound against certain microbe, this guarantees better treatment and fewer side effects. Further studies should be conducted on more virulent fungi and other cell forms.

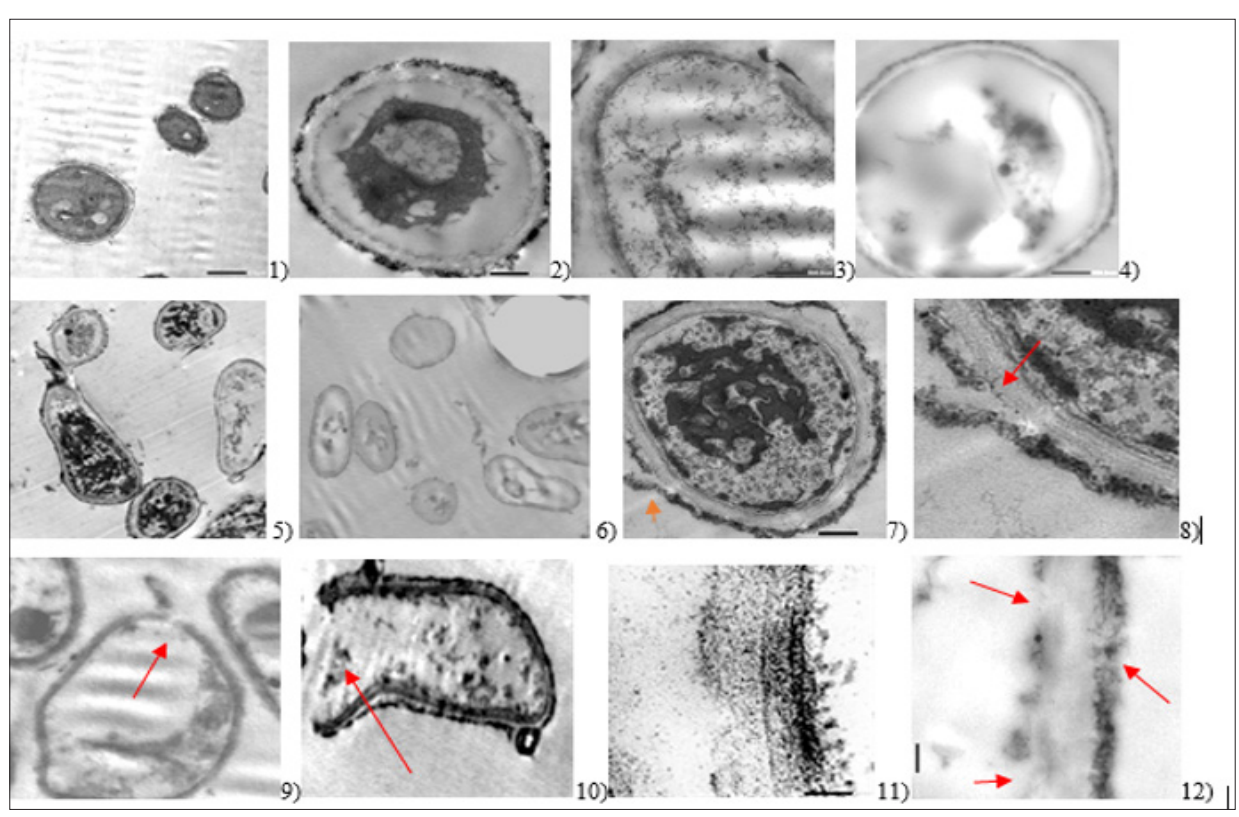

Figure 1: Transmission electron microscope images indicating apparent morphological changes in appearance of formed $A$. flavus ghost cells. 1) A. flavus control; 2) the cells showing aggregation of the cytoplasmic content after treatment; 3) partial loss of the cytoplasmic content; 4) nearly complete loss of the cytoplasmic content; 5) the appearance of evacuated cells but non evacuated cells still exist; 6) nearly all cells lost their cytoplasmic content; 7) and 8) single pore in the surface of the fungus; 9) single pore with significant loss of the cytoplasmic content in the fungal ghost cell; 10) big pore and the cell nearly evacuated; 11) and 12) different cell wall images show the degradation due to the effect of the treatment. Red arrows refer to the presence of pores in cell wall of fungal ghost cells and the different changes due to treatment.

\section{Conclusion}

A. flavus is an important pathogenic fungus causing different kinds of problems to both human and animals. Its control could be achieved by using the concept of the Sponge-Like protocol where MIC and MGC of active chemical compounds were used. The randomization of the conditions highlights the effect of each of the used value. SDS is responsible for pore formation in the fungus cell wall while $\mathrm{H}_{2} \mathrm{O}_{2}$ is responsible for DNA degradation. A. flavus is turned to ghost cells. The transmission electron microscope gave better visualisation for $A$. flavus during its loss for the cytoplasmic content. Using both of MIC and MGC of the active chemical compounds could play a significant role in controlling the different fungal infections and expected to find a more selective protocol for treatment with minimum side effect on normal cells. A concept even could be used in cancer treatment.

\section{References}

1. Hedayati MTP, Warn PA, Bowyer P, Denning DW (2007) Aspergillus flavus: human pathogen, allergen and mycotoxin producer. Microbiology 153 (Pt 6): 1677-1692.

2. Mosquera J, Warn PA, Morrissey J, Moore CB, GilLamaignere, et al. (2001) Susceptibility testing of Aspergillus flavus: inoculum dependence with itraconazole and lack of correlation between susceptibility to amphotericin B in vitro and outcome in vivo. Antimicrobe Agents Chemother 45(5): 1456-1462.

3. Campbell CK (1994) Forms of aspergillosis: In The Genus Aspergillus pp. 313-320.

4. Vujanovic, Smoragiewicz W, Krzysztyniak K (2001) Airborne fungal ecological niche determination as one of the possibilities for indirect mycotoxin risk assessment in indoor air. Environ Toxicol 16(1): 1-8.

5. Vanden Bergh MF, Verweij PE, Voss A (1999) Epidemiology of nosocomial fungal infections: invasive aspergillosis and the environment. Diagn Microbiol Infect Dis 34(3): 221-227.

6. Zaini FH (1995) Study of airborne fungi in the wards of 3 Tehran hospitals. J Med Council Islam Repub Iran 13: 17-21.

7. Hussain ZM, Amra AA (2016) Case-by-case study using antibiotic-EDTA combination to control Pseudomonas aeruginosa. Pak J Pharm Sci 19(3): 236-243.

8. Amara AA, Salem-Bekhit MM, Alanazi FK (2013) Sponge-like: a new protocol for preparing Bacterial Ghosts TSWJ 23: 89.

9. Laemmli UK (1970) Cleavage of structural proteins during the assembly of the head of bacteriophage T4. Nature 227: 680-685.

10. Makino K, K Yokoyama (1999) Complete nucleotide sequence of the prophage VT2-Sakai carrying the verotoxin 2 genes of the enterohemorrhagic Escherichia coli 0157: H7 derived from the Sakai outbreak. Genes \& genetic systems 74(5): 227-239. 
11. Panthel KW, Jechlinger (2003) Generation of Helicobacter pylori ghosts by PhiX protein E-mediated inactivation and their evaluation as vaccine candidates. Infect Immun 71(1): 109-116.

12. Dong H, X Han (2012) [Mutation of lambdapL/pR-cI857 system for production of bacterial ghost in Escherichia coli]. Sheng Wu Gong Cheng Xue Bao 28(12): 1423-1430.

13. Weibull C (1956) The nature of the ghosts obtained by lysozyme lysis of Bacillus megaterium. Exp Cell Res 10(1): 214-221.

14. Witte A, G Wanner (1992) Dynamics of PhiX174 protein E-mediated lysis of Escherichia coli. Arch Microbiol 157(4): 381-388.

15. Hensel A, V Huter (2000) Intramuscular immunization with genetically inactivated (ghosts) Actinobacillus pleuropneumonia serotype 9 protects pigs against homologous aerosol challenge and prevents carrier state. Vaccine 18(26): 2945-2955.

16. El-Baky NA, AA Amara (2014) Newcastle disease virus (LaSota strain) as a model for virus Ghosts preparation using $\mathrm{H}_{2} \mathrm{O}_{2}$ bio-critical concentration. International Science and Investigation journal 3(5): 3850 .

17. Amara AA, AJ Neama (2014) Evaluation the surface antigen of the Salmonella typhimurium ATCC 14028 ghosts prepared by SLRP. Scientific World Journal 2014: 840863.

18. Amara AA (2015) Saccharomyces cerevisiae Ghosts Using the SpongeLike Re-Reduced Protocol SOJ Biochem: 1-4.

19. Amara AA (2015) Bacterial and Yeast Ghosts: E. coli and Saccharomyces cerevisiae preparation as drug delivery model ISIJ Biochemistry 4(7): 11-22.

20. Delley PA (1999) Cell wall stress depolarizes cell growth via hyperactivation of RHO1. J Cell Biol 147(1): 163-174.

21. Sambrook J, EFF T Mainiatis (1989) Molecular Cloning a Laboratory Manual, Cold Spring Harbor Laboratory, Cold Spring Harbor, ( $\left.2^{\text {nd }} e d n.\right)$, NY, USA.

\section{ISSN: 2574-1241}

DOI: $10.26717 / B J S T R .2018 .10 .001926$

Amro Abd Al Fattah Amara. Biomed J Sci \& Tech Res

cC (i) This work is licensed under Creative

Commons Attribution 4.0 License

Submission Link: https://biomedres.us/submit-manuscript.php
22. Amara AA (2016) The critical activity for the cell all degrading enzymes: Could the use of the lysozyme for microbial ghost's preparation establish emergence oral vaccination protocol? International Science and Investigation Journal 5(2): 351-369.

23. Amara AA (2017) Smart green technology for microbial ghosts preparation. IIOABJ 8(5): 53-54.

24. Amara AA (2016) Lysozymes, Proteinase K, Bacteriophage E Lysis Proteins, and some Chemical Page 16 of 16 Compounds for MGs Preparation: a Review and Food for Thought. SOJ Biochem 2(1): 1-16.

25. Amara AA (2016) Vaccine against pathogens: A review and food for thought. SOJ Biochemistry 2(2): 1-20.

26. Hedayati MT, Mayahi S, Aghil R, Goharimoghadam K (2005) Airborne fungi in indoor and outdoor of asthmatic patients' home, living in the city of Sari. Iran J Allergy Asthma Immunol 4(4): 189-191.

27. Link HF (1809) Observations' in Ordines plantarum naturales. Dissertation prima, complectens Anandrarum ordines Epiphytas, Mucedines Gastomycos et Fungos Der Gesellschaft Naturforschender Freunde zu Berlin. Magazin für die neuesten Entdeckungen in der gesamten Naturkunde 3(1): 1-42.

28. Menisy MM, H Ghazy A, Sheweita S, Amara AA (2017) Klebsiella pneumoniae Ghosts as Vaccine Using Sponge Like Reduced Protocol. Cellular and Molecular Medicine 3(2): 8.

29. Wu X, Ju X, Du L, Yuan J, Wang L, He R, Chen Z (2017) Production of Bacterial Ghosts from Gram-Positive Pathogen Listeria monocytogenes. Foodborne Pathogens and Disease 14(1): 1-7.

30. Vinod N, Oh S, Kim S, Choi CW (2014) chemically induced Salmonella enteritidis ghosts as a novel vaccine candidate against virulent challenge in a rat model. Vaccine 32: 3249-3255.

31. Vinod N, S Oh (2015) Generation of a Novel Staphylococcus aureus Ghost Vaccine and Examination of Its Immunogenicity against Virulent Challenge in Rats. Infect Immune 83(7): 2957-2965.

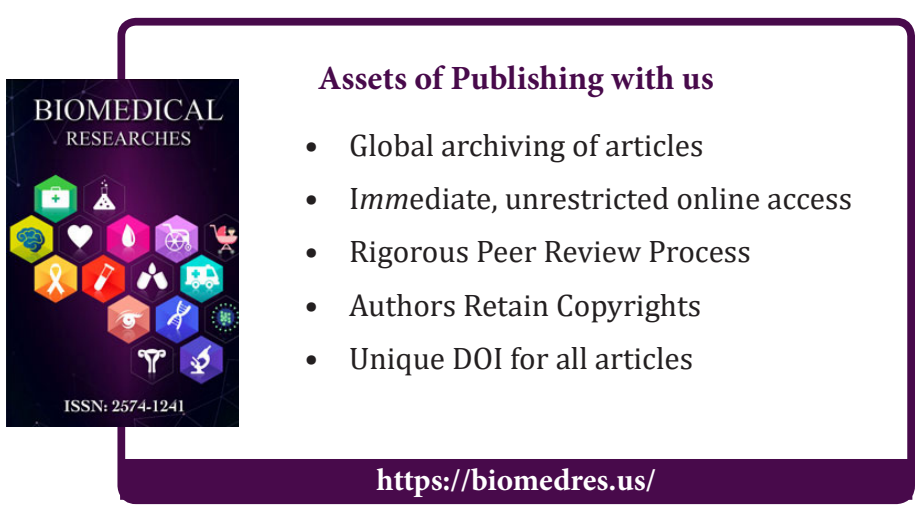

